\title{
Self-Advocacy: Enhancing the Education of Down Syndrome Learners
}

\author{
Dr Susette T Brynard \\ University of the Free State, South Africa, P O Box 12752, Brandhof, 9324, South Africa \\ brynards@ufs.ac.za
}

\section{Doi:10.5901/mjss.2014.v5n27p576}

\begin{abstract}
The aim of the article is to provide Down syndrome (DS) learners with better educational opportunities by implementing the principals of self-advocacy, at school level. A literature review was done to obtain background information on the concepts of $D S$ and the self-advocacy program. Qualitative research methods like art-based research combined with a narrative approach was implemented to get information from the participants because they could not always verbalise their feelings. From the findings it can be deduced that some of the principals underlying the self-advocacy movement can be used to enhance the educational opportunities of DS learners. The contribution this article makes is to apply the ideas of the self-advocacy movement to the education of learners with DS, as a possible way to give these learners a voice. The assumption is that if they can give input regarding their education, it will improve their opportunities to become valued human beings.
\end{abstract}

Keywords: Down syndrome, self-advocacy, inclusive education, intellectual disabilities, social justice.

\section{Introduction}

Down syndrome is a genetic condition caused by an extra copy of chromosome 21. It is characterised by unique features and abilities in the physical and cognitive areas of human development (DSSA 2011). Although each person with Down syndrome has features that are shared with others, there are more differences than similarities between these individuals (Selikowitz 2008).

The birth of the self-advocacy project in South Africa in 2009 started a new era of empowering young adults with Down syndrome (DS) and other intellectual disabilities in this country. If it is taken into account that $12 \%$ of the people in South Africa have special educational needs, we are talking of more than 220000 learners (Rademeyer 2010). A forum was set up by Down Syndrome South Africa (DSSA) to provide these young adults with a place where they can stand up and speak for themselves, in order to have their rights upheld and be respected as individuals (DSSA 2010a).

The self-advocacy movement is a civil rights movement for people with developmental disabilities, to enable them to take control of their own lives. It means that although a person with a disability may use the support of others, he/she is entitled to be in control of his/her own resources and how they are directed. Disabled people are often some of the most powerless members of society and many have never been part of the decision-making process relating to their educational needs (DSSA 2009). It is argued that some of the elements underlying the self-advocacy movement can be used to enhance the educational opportunities of DS learners.

Self-advocacy enables people with DS to make choices and decisions that control their lives but it is difficult to give a single definition of self-advocacy because it has grown in complexity over the years (Goodley 2009). The advocacy movement is grounded on the principles of social justice, which recognises that all human beings possess certain values which they can add to society (Kliewer 1998). All people have human rights because they are human and nobody is more or less human than anyone else; thus, nobody has more or less human rights than anyone else. A right is not what someone gives you; it is what no one can take from you (Guernsey \& Stein 2008). The Self-Advocacy Movement of South Africa (SAMSA) puts persons with DS in a position where they understand and know their rights, so that they are able to make their own decisions about aspects that might influence their lives and which will empower them as dignified human beings (DSSA 2010b).

All learners should be involved in creating and making decisions about their own learning and development (Bansilal James \& Naidoo 2010). To listen to the voices of learners in the learning interaction is important for teachers, but also for learners. By giving learners a voice, one is able to receive critical responses that can inform and ultimately, also play a role in their success. However, the voices of many learners are still being compromised in the structure of school governance (Mabovula 2009). The aim of the article is to show how the ideas that form the basis of the selfadvocacy movement can give DS learners a voice to enhance their educational opportunities. 
Disability is an international phenomenon and sadly, many of these people often remain uneducated and unemployed because their potential is not acknowledged. A lack of awareness of their abilities, as well as negative attitudes and prejudice from people without disabilities, are the main reasons for this situation (Kleinhans \& Kotze 2010). One may question the receptivity of people's thoughts about handicapped people, when their lives are not touched by them in some or other way. Too little exposure of these people in society necessitates a more open approach to collaboration in all spheres of life, of which education is one. Before the twenty-first century, Kliewer (1998) had already stressed the importance of the advocacy movement, which emerged in resistance to the history of segregation. The effectiveness of any educational system is questioned when many learners with disabilities are without educational opportunities. Although many western countries provide a number of services, including educational services to people and families with DS, there is still an enormous amount of work to be done (Robertson 2009).

In the following section, the theoretical background of the concepts Down syndrome and their educational opportunities, as well as the self-advocacy movement are discussed. The results of a qualitative research project on the self-advocacy movement in the Motheo Educational District in South Africa will be reported on. The article concludes with guidelines to improve the current educational opportunities of DS learners, by using the principals of self-advocacy.

\section{Theoretical Framework}

The perceptions and attitudes towards people with DS have changed dramatically during the last few years. Only fifty years ago, children with DS were still routinely institutionalised and parents were encouraged to leave their new-born babies in the paediatric ward or to put the child in an institution where they usually died from infections and medical neglect. Today, there is a growing realisation of the potential of children with DS not to be institutionalised, but to give them opportunities to become part of society (Merrick 2006; Parker 2010). In spite of the improvements that have been made, there still exists a stigma associated with DS. Many people still hide their children and those in the medical profession can be very insensitive in their remarks made to parents of new-born DS babies (Parker 2010). A primary physician should rather act as the coordinator of care for a child with DS; thus helping the family as a unit and each DS individual, to achieve the highest level of independence (Urkin 2006). The independence of learners with DS relates to their educational needs and forms part of the ideals of the self-advocacy project.

Down syndrome is the most common non-inherited organic cause of mental retardation that occurs in approximately one of every 650 live births (Hovorka \& Naznin Virji-Babul 2006). Although there are genetic similarities and differences between learners with DS, it is necessary for teachers to be aware of their common physical characteristics, so as to be able to feel confident in teaching them (Selikowitz 2008). Knowledge about the possible medical problems these learners may have is also important and can help teachers to handle them with the necessary care (Schneider, Wedgewood, Lewellyn \& McConnell 2006).

Over the past two decades, the approach for the provision of education to learners with different educational needs in South Africa has been undergoing significant changes. Previously, it was practice to exclude anyone from formal education who was perceived as 'different'. The education they did receive relied on the 'generosity and goodwill' of individuals or charity groups (Green \& Engelbrecht 2009). After the Education White paper 6 gazetted the Policy on "Building an Inclusive Education and Training system" in 2001, one of the first things the Department facilitated was to select and support a number of ordinary schools to become full service schools to accommodate DS learners, as well as many other learners with learning disabilities (Schoeman 2009).

Educational opportunities for learners with DS imply overcoming socio-cultural prejudices and social barriers. Niemann (2006) adds to the above by stating that it is necessary to respect differences in people, which will contribute to the knowledge and understanding of reality. It also involves rehabilitative and training actions to address the different educational needs that characterise a heterogeneous group of students. Having the same rights does not necessarily mean being able to benefit from the same interventions (Nota 2006).

When research is done on the educational views of learners, it focuses mainly on the learners without special educational needs in the main population groups and very little on learners with learning problems (Steyn, Badenhorst \& Kamper 2010). The self-advocacy movement takes cognisance of the above arguments by deliberately giving learners with DS the opportunities to speak for themselves and also to help them to respect themselves and their abilities. Over the past thirty years the self-advocacy movement has catered for people with learning difficulties so that they can support one another, as well as speaking out about discrimination against them. This can be done individually or collectively, with or without the support of others (Goodley 2009). Although it does not exclude individual self-advocacy, it focuses mostly on people who decide to lobby in a group. It can also be seen as a self-help group practice (Suthcliffe \& Simons 1993).

A number of ideals that characterise the self-advocacy movement are that the DS members should learn to go 
beyond their typical roles to represent themselves or other people, in a way that will help them to cope with reality. People with DS should also learn that it is their right to be treated as equals and that they should be given the opportunity to speak out and make decisions to empower themselves (Goodley 2009). Self-advocacy can facilitate self- expression; thus highlighting the ability to represent ones-self and others. In context, it can also mean self-development. This movement focuses on group activities of people with learning difficulties to challenge institutional prejudice and oppressive authority in society (Goodley 2009).

The aim of self-advocacy is a self-determination process which focuses on the following principals: freedom, which means the right to dream and plan your own life with the necessary support by choosing to take charge of your life; authority, over your needs, with the help of others, because you honour, value and love yourself; support, which should be arranged to assist in everyday living, because you have the right to ask for help; and responsibility, which also reflects on the community, to employ and value the contributions of an individual, because they stand up for themselves (Pennell 2001; Self Advocacy Association of New York state 2011; Mintz 2011). This said, it is also important for the individual to respect the needs of other people.

Many of the elements of self-advocacy can be developed in these learners when they are educated according to the above principals, such as the understanding of choice, feeling valued, understanding the world with its possibilities and difficulties better, improved feelings of self-worth, developing skills and competencies, being able to take risks, feeling confident, encouraged and supported while developing towards autonomy (Goodley 2009; Mittler 1984). In this research, the ideals of this movement will be used to propose appropriate educational opportunities for all learners with DS, irrespective of the schools they attend.

\section{Research Methodology}

This research was undertaken from an interpretive framework, because it refers to a deeper search for meaning which incorporates feelings (Henning 2011; Waghid 2003). Since some of the participants have a speech impairment, visual, arts-based research was done where the participants were asked to answer the questions by making drawings. According to Levine (2004), art has the capacity to reveal a deeper truth about human existence.

The above approach was combined with a narrative approach when the participants were asked to explain their drawings by means of probing during unstructured interviews. The participants then explained their perspectives by using story structures (Sinclair Bell 2002). A narrative research approach was used to acquire a richer understanding of the issues involved, as this approach allows the researcher to obtain information that people do not consciously know themselves, and more importantly, it allows the researcher to understand the insights of the participants. In the case of the adult who could not verbalise clearly, he also used sign language to explain his drawings.

This narrative research approach requires close collaboration between the researcher and the participants and their situation. In this study, the focus was on combining research activities with other activities which the participants chose and enjoyed, such as playing pinball and having a meal together. Qualitative research helps the researcher to gain insight and understanding into the life of the research participants (Henning 2011; Mouton 2003). Art-based research can also adapt to almost any qualitative methodology (Smithbell 2010). Qualitative research seeks to understand phenomena without the researcher attempting to manipulate the phenomena (Patton 2002). This approach emphasises the role of the researcher's experience of and insight into the phenomenon under investigation (Henning 2011), which in this case, is appropriate. I (the researcher) have a daughter of 30 years old with DS. Therefore, the method of research is appropriate to my ontological (what is reality?) and epistemological (how does one know something?) assumptions about DS (Harrits 2011).

\subsection{Interventions}

The intervention started after the first drawings were made at the beginning of the first contact session and stopped before the last drawings, during the last contact session. During each intervention I focused on the four principals of selfadvocacy. The explanations and practical applications were done interactively with the help of hand dolls, role play and acting. I stressed the importance of their rights as human beings, emphasising the fact that they have the authority to choose the activities during the interventions. This gave them self-confidence and a feeling that they were valued, together with a feeling of self-worth. I also gave each participant the freedom to speak and draw what and how they wanted to and enough time to verbalise to me what their drawings meant in their lives and how they related to their worlds with its possibilities and difficulties. They had the right to my support and attention and also to the support of the other participants, and at the same time, the responsibility to keep the needs of the other participants in mind. 
From my own experience with my daughter, I realised the importance of being strict but loving during interventions, as well as not being allowed to be manipulated. I explained to them that taking risks was a skill they could pursue, because I focused on their feeling valued as human beings, with the right to make choices and decisions about their lives. When one participant wanted all the attention, which happened frequently, I explained to them the rights and responsibilities of each individual in the group, corroborated with practical examples. During the interventions I applauded their efforts and I never focused on their incompetence. I demanded socially acceptable behaviour at all times, without forcing it. By encouraging humour, we could laugh at ourselves and enjoy the activities.

\subsection{Data collection}

I made use of the purposive sampling method. The group of DS adults who are part of the self- advocacy movement in the Motheo District in South Africa was used as the target group. It is a group of 4 adults who differ in age and development and come from different backgrounds. The group was chosen because members volunteered to become part of the self-advocacy movement after its official launch in the Motheo District.

Data were collected interactively by making use of drawings, unstructured interviews and also by making observations of the young adults while they did different activities. After the individuals had completed their drawings, questions were asked about the stories the drawings depicted. I wanted to find out from them what their needs were, how much self-confidence they had and how they understood the responsibilities that come with freedom. I needed to find out whether their understanding and the application of the principals of self-advocacy had improved, due to the interventions. The questions were open-ended and sometimes they had to be rephrased so that the participant could understand what was meant. I did not use a specific number of questions and when I understood what the participants wanted to communicate to me, I stopped asking questions. Answers related mostly to the participants' drawings, but sometimes other remarks and actions from the group also provided additional information on their perspectives about themselves in relation to the surrounding world.

\subsection{Data analysis}

The birth of my daughter more than 30 years ago stimulated me to conduct an informal study of DS lasting nearly 30 years. I read everything I could find on the topic and visited many people with DS nationally and internationally. I have learned to understand the spectrum within which these learners tend to think and operate, although each learner differs in the way he/she experiences and handles life. I believe I can interpret their drawings, especially as each participant explained and clarified his/her drawing by telling me the story underlying it. The participants trusted me and I treated them with respect and affection, while acknowledging their different needs and abilities.

This study does not propose to be entirely objective, although I tried to be as objective as possible. I used my experience to try to understand the young adults and their needs. I did this by 'role playing', which can contribute to objectivity in qualitative research, because it is a 'spiritual' activity through which the researcher imagines him/herself in the position of another to understand, anticipate and interpret the behavior or experiences of another (Niemann, Niemann, Brazelle, Van Staden, Heyns \& De Wet 2000).

Working with people with DS is a sensitive situation of which I am well aware, through the exposure I have had with my DS daughter. I thus respect their privacy and approached each individual with sensitivity. I have learnt to love and care for people with DS and other intellectual disabilities and I respect their needs to live a full life with all the opportunities (which include educational opportunities), that people without disabilities have. The parents and participants gave their consent to this study, the adults will not be identified and the results dealt with in a respectful way.

\section{Results}

After the drawings were interpreted with the help of unstructured interviews, they were analysed by determining each participant's growth according to the principals of self-advocacy. To be able to express ones-self by means of drawings is of special importance for people with speech impairments. This links to the ideas of Eisner (1995) whose results showed that artistic self-expression reveals aspects of the self and puts us closer in touch with what we really feel, leading to a deeper knowledge of the self. Thus, self-report evidence is valuable for inquiry into human experience. The following results were found: 


\subsection{Participant 1}

This participant was a girl of 32. She had problems relating to the group in the beginning and lacked certain social skills. She wanted to have all my attention and repeatedly asked me the same questions, which indicated her insecurity. From the drawings and interviews, it was also clear that her self-esteem was very low before the interventions started. She lacked the self- confidence to draw herself and it was only after the second intervention, that she acquired the courage, although she still drew herself as very small. The things she related to were all around the house, such as a television and the road passing their house. After the last intervention she started to express dream-like qualities in her drawings, adding the sea, the sun and even a dolphin. Her answers which related to her drawings also confirmed her insecurity in the beginning and her growth at the end of the last session. After the third intervention she expressed the desire to learn to read and write, which was not important to her previously. This was a clear indication of the positive development in her self-concept, which gave her the confidence to speak about her educational needs.

\subsection{Participant 2}

This participant was boy was 25 . He could not speak understandably and used sign language to communicate. Before the first intervention, he did not have the courage to draw but allowed his mother to make a basic drawing of him. The only thing he added to her drawing was his muscles. In his first drawing it was clear that his muscles were very important to him. He had a rather healthy self-concept because of his swimming, but it was apparent that he could only relate to the fact that he was strong and that he could swim well. His mother had to be with him during the first intervention, but thereafter, he developed the courage to let her go. He lacked social skills and he focused only on his own muscles and his own needs before the first intervention. During the second session his mother left and I had to draw 'him'. He again added his muscles first, illustrating the fact that it was still the most important characteristic he sees in himself, but he also added features (which his mother had to do the previous time) such as hair and colour to his face. He then added a swimming pool, which illustrates that he realised that he could be seen in relation to the outside world. During the third session his growth became even more apparent. He drew himself for the first time and added his family, home and even their cars. He listened to the group when they pointed out any bad manners and in this way, his social skills improved and the group accepted him. For the first time, he did not want me to use sign language and tried to talk to me, which illustrated the self-confidence he had acquired. He could actually express his educational need to learn to talk, which he had never done previously.

Because of space I only attach the drawings of participants 2 and 4.

\section{Drawings of participant 2}

Fig 1: Drawing 2.1

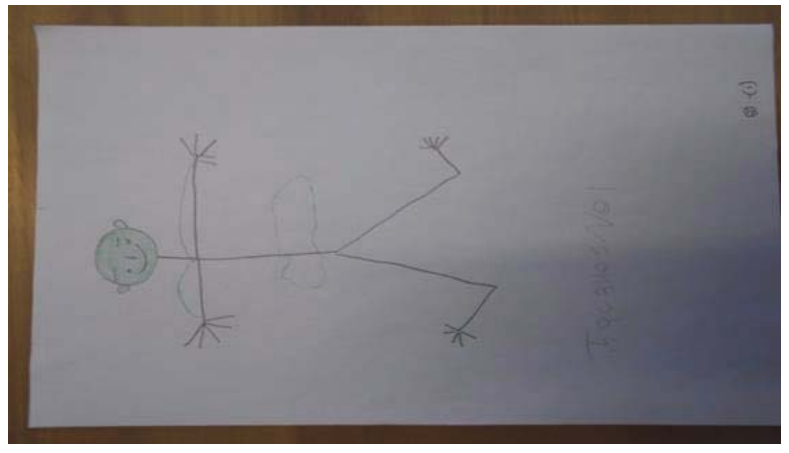


Fig 2: Drawing 2.2

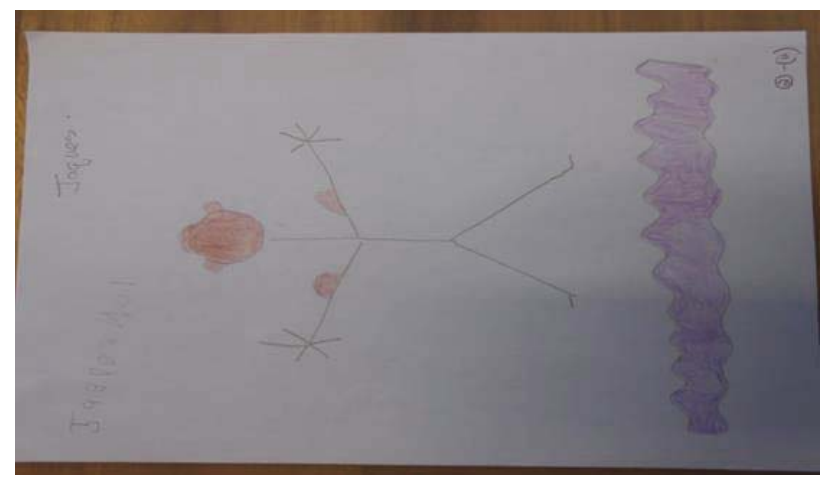

Fig 3: Drawing 2.3

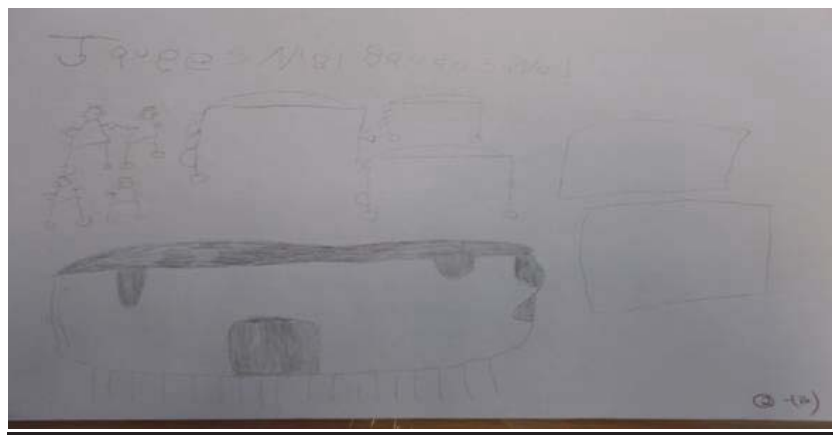

\subsection{Participant 3}

This participant was a girl of 30. In the first drawing she seemed to see herself as a lovely girl with a big smile and prominent glasses. The image she had of herself was good, although she was reserved and stood back to give the other participants opportunities when socialising, thereby demonstrating her unwillingness to speak out in the group. From the second session onwards, she started to articulate some of her rights and expressed a definite view on the needs of learners like herself. In the second and third drawings she added people, a computer and all kinds of educational articles. Subsequently, she did not see herself as alone any more, but in relation to the others. Although she was still somewhat reserved during the second intervention, her self- confidence grew and in the last session, she attempted to incorporate participant one who did not mix with the group, as well as participant two who could not speak well. For the first time, she realised that she has the right to her opinion and her needs. She started to articulate her feelings about her rights and responsibilities and began to take the lead in the group.

\subsection{Participant 4}

This participant was a girl of 18. The first drawing seemed to illustrate her good self-concept, as she filled the whole page with 'herself' and the stories relating to her drawings confirmed this fact. She drew herself in a wedding dress and told me that she is going to marry the new teacher at school. Her life revolved around this wish. She joined in the conversations but talked mostly to me during the first session, which illustrates her insecurity. Her second and especially her third drawings illustrated her growth as a person. She still wanted to marry the teacher but there were also other activities, such as judo that fill her life. Her happiness and the love she experiences were illustrated by the red hearts in her drawings. The many different aspects of her life illustrated in her drawings and the answers she gave me, indicate the many dimensions of her life she now focuses on. During the last session she started to express her feelings about the rights and responsibilities of all people, including those with DS. She focused strongly on the right of a person to say "no" to unwanted sexual advances. 


\section{Drawings of participant 4}

Fig 4: Drawing 4.1

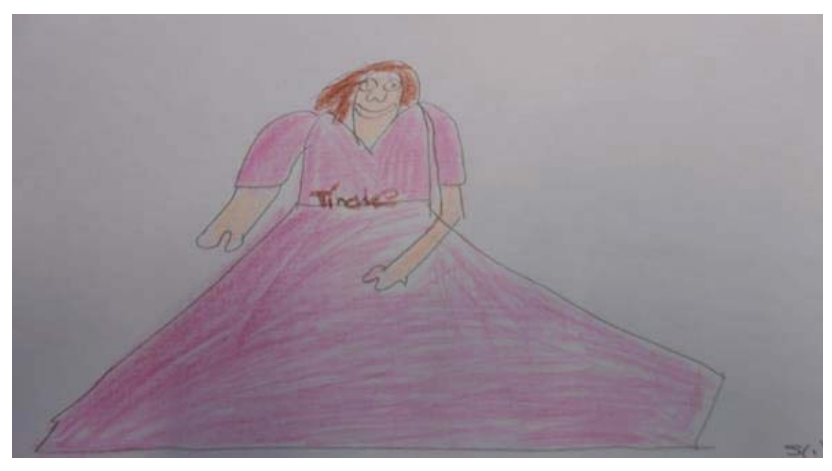

Fig 5: Drawing 4.2

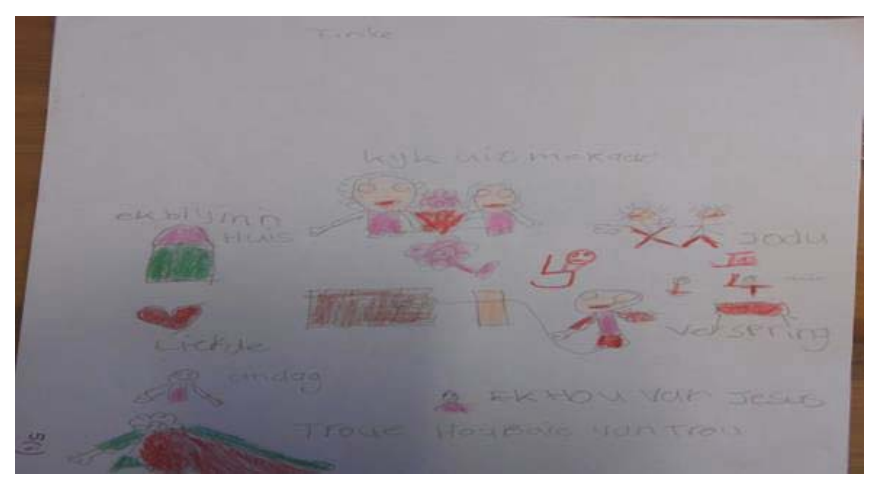

Fig 6: Drawing 4.3

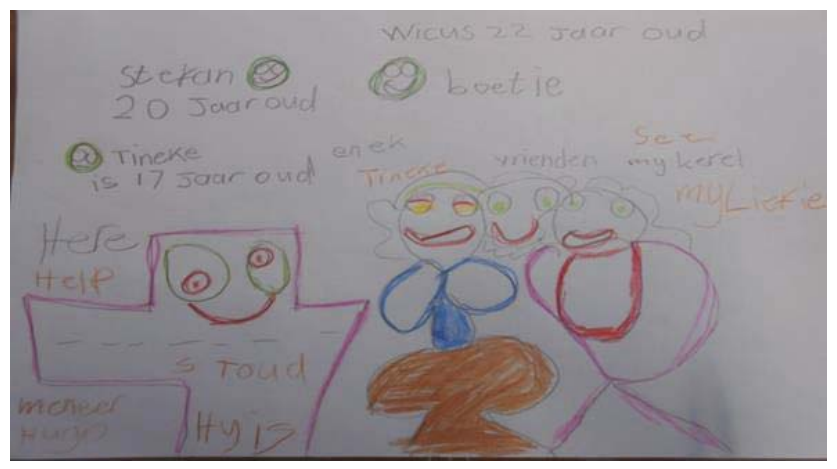

\section{Discussion}

During interventions I realised that I would not have been able to accomplish the same amount of work with more participants during a session, because of their different intellectual and developmental levels. If these young adults could benefit from only three interventions, the impact of such a programme in schools, over a period of time, should be considered; although teachers making use of these ideas in a bigger group might need more sessions to reach the same outcomes.

The development in the participants' drawings indicates that the interventions based on the elements of selfadvocacy, seem to enhance the self-concept of all participants. At the beginning of the first session, they seemed very 
unsure of themselves, but after each intervention, their sense of themselves improved and they started to believe in their own competencies and rights to the freedom of choice. It became clear that the participants were capable of seeing themselves in relation to the world around them to a greater degree during the last session, because they made drawings of other people or structures surrounding the image they drew of themselves. Nevertheless, it is clear that their own importance was of primary concern to them before the interventions took place. In the interviews, some of them were assertive about their choices of 'interests' which surrounded the drawings of 'themselves'. This is an indication that they had become sufficiently confident to stand up for their rights and the freedom to express them. Two of them focused on their educational needs; one on her rights involving sexual advances; and the other on her right to have her own opinions and needs.

The above results correlate with the literature which states that the issues discussed during the interventions are principals of self-advocacy (Goodley 2009) which can promote the self-actualisation of learners with DS. If these developmental skills can receive attention in schools when DS learners are younger, there would be no need for a selfadvocacy programme for adults. All learners with DS will also benefit because not all learners enter a self-advocacy programme after school. It is important to realise that the research shows that many of the above opportunities will be lost if Down syndrome learners are not given access to the developmental opportunities of a self-advocacy programme during their school education.

\section{Conclusion and Recommendations}

The positive results that emerged at the end of the third session are an indication that all the participants benefited from the interventions. If the principles of self-advocacy could be taught to all DS learners from an early age in schools over a longer period of time, these learners should benefit exponentially. DS learners would be empowered to make some of their own choices from an early age, taking cognisance of the responsibilities that go with freedom of choice. The selfconfidence of DS learners should improve because they will have a better understanding of their rights and they will be able to believe in themselves and their abilities. They will be more inclined to stand up for what they believe in and their voices heard when education is planned for them.

Guidelines for teachers which emerged from the interventions are that teachers should free themselves from any bias they may have against learners with DS. They should also equip themselves with knowledge about the selfadvocacy programme and the possible implications thereof, at school level. The most important aspects that teachers should take note of and which emerged during the interventions in the study were to be strict, yet loving with the learners. Like any other learner, learners with DS need discipline. One should believe in their abilities and never expect too little of them. They should be treated the same way as other learners and not as if they are more or less, special than others. They should be given a chance to speak and their answers should be listened to. It might take a little longer to finish a sentence, but they should be given time to finish. As with all children, it is necessary to focus on what they can do and applaud their achievements, however small. Parents and teachers should stress the importance of socially acceptable behaviour in all spheres of life.

If learners with DS are exposed to society to a greater extent, more respect may be accorded them from all people, regardless of their differences. By applying the ideas of the self-advocacy movement to education, all learners will benefit, because it gives all human beings the right to take charge of their lives and to express their feelings in the correct way, keeping in mind their responsibility to respect their fellow human beings. By interrogating the results of the research it is clear that if the principals of the self-advocacy movement are implemented in the school structure of DS learners, it should help to address their educational needs and make a significant contribution towards their self-actualisation.

\section{References}

Bansilal, S., James, A. \& Naidoo, M.(2010). Whose voice matters? Learners. South African Journal of Education, February(1), $153-165$. DSSA.(2009). Sibaleni Nathi Count us in, September(5). Johannesburg, Publication of DSSA.

DSSA.(2010a). Nothing about us, Self-advocacy project, terms of reference, Unpublished document: Johannesburg.

DSSA.(2010b). Sibaleni Nathi Count us in, March(6), Johannesburg, Publication of DSSA.

DSSA.(2011). Sibaleni Nathi Count us in, June(7), Johannesburg, Publication of DSSA.

Eisner, E.(1995). What artistically crafted research can help us to understand about schools. Educational Theory, 45(1), 1-13.

Goodley, D.(2009). Self-advocacy in the lives of people with learning difficulties, New York, Open University Press.

Green, L. \& Engelbrecht, P.(2009). An introduction to inclusive education in Responding to the challenges of inclusive education in Southern Africa, Pretoria, Van Schaik.

Guernsey, K. \& Stein, P. J. S.(2008). Change your life with human rights, Publication of the Harvard Law School Project on Disability. 
Harrits, G. S.(2011). More Than Method? A Discussion of Paradigm Differences Within Mixed Method research. Journal of Mixed Methods Research, 5(2), 150-166.

Henning, E.(2011). Finding your way in qualitative research, Van Schaik, Pretoria.

Hovorka, R. M. \& Naznin Virji-Babul, P. T.(2006). A preliminary investigation into the efficacy of virtual reality as a tool for rehabilitation for children with Down syndrome. International Journal on Disability and Human Development, October-December(5), 309. London-Tel Aviv, Freund Publishing House Limited.

Kleinhans, R. \& Kotze, M.(2010). Bestuurders en werknemers se houding teenoor persone met fisieke gestremdhede in die werkplek. Tydskrif vir Geesteswetenskappe, September(3), 404-417.

Kliewer, C.(1998). Schooling children with Down syndrome. Toward an understanding of possibility, New York, Teachers College Press.

Levine, S.(2004). Arts-Based Research: A Philosophical Perspective. The Journal of Pedagogy Pluralism \& Practice(9), 1-4.

Mabovula, N.(2009). Giving voice to the voiceless through deliberative democratic school governance. South African Journal of Education, May (30), 219-233.

Merrick, J.(2006). Editorial. International Journal on Disability and Human Development, October-December(5), 309. London-Tel Aviv, Freund Publishing House Limited.

Mintz, S. G.(2011). Self-advocacy for family caregivers. www.comfortofhome.com (Retrieved 11 November 2013).

Mittler, P.(1984). Quality of life and services for people with disabilities, Bulletin of the British Psychological Society, 37 July, 218-215.

Mouton, J.(2003). How to succeed in Your Master's and Doctoral Studies: A South African Guide and resource Book. Pretoria, Van Schaik.

Niemann, R. Niemann, S. Brazelle, R. Van Staden, J. Heyns, M., \& De Wet, C.(2000). Objectivity, reliability and validity in qualitative research. South African Journal of Education, 20(4), 283-286.

Niemann, R.(2006). Managing workplace diversity in South African schools. South African journal of education, 26(1), 97-112.

Nota, L.(2006). Facilitating school inclusion. International Journal on Disability and Human Development, October-December, (5), 309. London-Tel Aviv, Freund Publishing House Limited.

Parker, F.(2010). Don't let it bring you down. Mail and Guardian, 26 March 2010.

Patton, M. Q.( 2002). Qualitative Evaluation and Research Method, 3rd ed. Thousand Oaks, CA, Sage Publications, Inc.

Pennell, R. L.(2001). Self-determination and Self-Advocacy: Shifting the Power. Journal of Disability Policy Studie,11(4), 1-9.

Rademeyer, A.(2010). Kurrikukum vir leerlinge met spesiale leerbehoeftes "ontoepaslik". Volksblad. 17 September 2010: Nasionale Pers.

Robertson, P.(2009). Sibaleni Nathi Count us in, September 2009 (5). Johannesburg, Publication of DSSA.

Schneider, J., Wedgewood, N., Lewellyn, G., \& McConnell, D.(2006). Families Challenged by and Accommodating to the Adolescent Years. Journal of intellectual Disability Research, 50(12), 926-936.

Schoeman, M.(2009). Sibaleni Nathi Count us in, September (5). Johannesburg, Publication of DSSA.

Self Advocacy Association of New York state, Inc, sa. Summary of Self-determination. http://www.sanys.org/determination/deter_3.htm: (Retrieved November 2011).

Selikowitz, M.(2008). Down syndrome the facts. Oxford, Oxford University Press.

Sinclair Bell, J.(2002). Narrative Inquiry: More than Just Telling Stories. TESOL Quarterly, 36(2), 207-209.

Smithbell, P.(2010). Art-Based Research in Education: A Review. The Qualitative Report, 15 (6), 1597-1601.

Steyn, M., Badenhorst, J., \& Kamper, G.(2010). Our voice counts: adolescents' view on the future in South Africa. South African Journal of Education, May, 2010 (2): 169-189.

Suthcliffe, J., \& Simons, K.(1993). Self-advocacy and Adults with Learning Difficulties. Context and Debates. Leicester, National Institute of Adult Continuing Education.

Urkin, J.(2006). Care of children with Down syndrome. Sharing and dividing responsibilities between the community physician and subspecialists. International Journal on Disability and Human Development, October-December 2006 (5), 319- 322. London-Tel Aviv, Freund Publishing House Limited.

Waghid, Y.(2003). Democratic Education - Policy and Praxis. Stellenbosch University, Matielandprinters. 